\title{
PENGEMBANGAN MEDIA MONOPOLI MATEMATIKA PADA MATERI PELUANG UNTUK SISWA SMP
}

\author{
Desya Rossa Deviana, Erlina Prihatnani \\ Program Studi Pendidikan Matematika Universitas Kristen Satya Wacana Salatiga
}

\begin{abstract}
This study aims to develop Monopoly Mathematics Media (Monomath) to learning mathematical probability exercises at junior high school. Using the ADDIE model consist of five phases - Analyze, Design, Development, Implementation, and Evaluation to develop this Monomath Media. This Monomath has gone through validity, practicability, and effectiveness test. The result of this research showed that the Monomath obtained a total average score for all aspect were $78.1 \%$ of validity matter expert and $80.8 \%$ of validity media expert, which means the media is valid. In the feasibility, the study result obtained a total average score for all aspect were $82.5 \%$, which means the media has met practical criteria. The field trials result was obtained an average score of 95.46 for the posttest. It is higher than pretest average score was 54.83 . The result of the student questionnaire showed that an average score of $90 \%$ which means the student give a positive response to the Monomath they used. Thus, the result of Monomath to learning mathematical probability is valid, practical, and effective.
\end{abstract}

Keywords: Monopoly mathematics media; Probability; ADDIE model

\section{PENDAHULUAN}

Matematika merupakan salah satu mata pelajaran yang berperan penting dalam kehidupan manusia. Acharya (2017) menyatakan bahwa "Mathematics is the one of the most importance subject in our human life". Oleh karena itu, matematika perlu dipahami oleh peserta didik dari jenjang pendidikan dasar sampai pendidikan tinggi.

Matematika merupakan salah satu mata pelajaran yang menekankan konsep. Rahaju dan Hartono (2015) menyatakan bahwa pembelajaran matematika sering difokuskan pada pemberian sejumlah konsep. Menurut Rohana, Hartono, dan Purwoko (2009), penguasaan konsep siswa pada mata pelajaran matematika masih lemah bahkan pemahamannya masih keliru. Guna memperdalam pemahaman konsep guru dapat memberikan latihan soal. Jika siswa dituntut untuk mempelajari materi yang menekankan konsep, secara otomatis siswa memerlukan banyak latihan soal dan ulangan (Supriyono, 2012). Hal ini menunjukkan bahwa latihan soal merupakan salah satu kunci keberhasilan dalam mata pelajaran matematika.

Metode latihan secara rutin dapat membantu siswa dalam meningkatkan 
pemahaman terhadap materi. Menurut Ramadhani (2017), pembelajaran matematika pada umumnya lebih berkonsentrasi pada latihan soal daripada pengertian. Metode latihan yang biasanya disebut dengan metode drill dapat membiasakan siswa dalam berlatih soal. Metode drill merupakan metode mengajar dengan cara melatih siswa terhadap materi yang sudah diajarkan agar memiliki keterampilan (Sudjana, 1995). Metode drill mempunyai manfaat diantaranya: 1) membentuk kebiasaan yang biasa dilakukan dengan menggunakan metode latihan soal akan menambah ketepatan dan kecepatan, 2) memanfaatkan kebiasaan yang tidak memerlukan banyak konsentrasi, dan 3) membentuk kebiasaan membuat gerakan yang komplek/ rumit menjadi otomatis, habitation makes complex movement more automatic (Sagala, 2012).

Metode drill banyak membawa manfaat. Namun, metode drill juga dapat berdampak negatif. Terkadang latihan yang dilakukan secara berulang-ulang merupakan hal yang monoton dan membosankan (Sagala, 2012). Oleh karena itu, guru perlu mengantisipasi munculnya rasa jenuh siswa pada saat menyelesaikan latihan soal. Sagala (2012) menyatakan bahwa cara yang dapat digunakan untuk mengurangi rasa jenuh siswa saat mengerjakan adalah soal latihan disajikan secara menarik, gembira, dan tidak membosankan. Fitri, Helma, dan Syarifuddin (2014) menyatakan bahwa dalam penyampaian materi, banyak cara yang dapat digunakan untuk menumbuhkan semangat belajar siswa salah satunya dengan menggunakan media pembelajaran yang sesuai dengan karakter siswa. Menggunakan media yang menarik merupakan salah satu cara yang digunakan untuk mengantisipasi rasa jenuh siswa pada saat latihan soal.

Menurut Sanaky (2009), Indriana (2011), Kustandi dan Sutjipto (2011), media pembelajaran merupakan sarana pendidikan sebagai alat perantara menerapkan pembelajaran untuk memperjelas informasi yang diajarkan guna mencapai tujuan pembelajaran. Media juga dapat digunakan untuk membantu pada saat proses pembelajaran. Menurut Arsyad (2011) fungsi utama media pembelajaran yaitu sebagai alat yang dapat membantu proses mengajar yang dapat dikemas dan diciptakan oleh guru atau pengajar. Menurut Sudjana dan Rivai (2013), media bermanfaat untuk meningkatkan motivasi belajar siswa, lebih memahami dan menguasai tujuan pembelajaran, sehingga lebih berinovasi dan kegiatan pembelajaran akan lebih banyak dilakukan oleh siswa.

Salah satu cara untuk menyajikan latihan soal secara menarik adalah dengan menggunakan media pernainan. Supriyono (2012) menyatakan bahwa penting bagi guru 
untuk mampu merancang model pembelajaran yang mengandung aktivitas dengan unsur permainan. Dengan adanya media permainan siswa tidak merasa jenuh pada saat latihan soal dikarenakan adanya tantangan dari suatu permainan. Menurut Tang, Hannegan, dan El-Rhalibi (2009) menyatakan bahwa pembelajaran berdasarkan permainan dapat digunakan untuk tujuan pembelajaran dan pendidikan seperti dukungan pembelajaran, peningkatan pengajaran, penilaian, dan evaluasi pembelajaran. Selain itu, pembelajaran berbasis permainan dapat mengembangkan pendidikan karakter seperti disiplin, jujur, dan kerja sama (Rahaju \& Hartono, 2015).

Terdapat beberapa media permainan yang telah dikembangkan untuk proses latihan soal salah satunya yaitu monopoli. Permainan monopoli merupakan papan permainan yang di dalamnya terdapat petak dan setiap pemain bisa membeli lahan pada petak tersebut sesuai dengan harga yang tertera, yang meliputi properti berupa aset bangunan dan tanah (Trinovitasari, 2015). Permainan monopoli juga dapat melatih siswa untuk mengatur keuangan.

Permainan monopoli telah dimodifikasi menjadi media yang dapat dimanfaatkan dalam pembelajaran. Beberapa penelitian bahkan telah mengembangkan media monopoli untuk digunakan dalam pembelajaran di SMP. Contohnya penelitian Fajar dan Prihatnani (2018) yang mengembangkan monopoli untuk pembelajaran matematika pada materi persamaan garis lurus, Ramadhani (2016) pada materi alat-alat optik, Firdaus (2015) pada materi sistem pencernaan. Dari beberapa media monopoli yang telah dikembangkan, terdapat beberapa kesamaan diantaranya terdiri dari komplek-komplek daerah yang disusun dalam papan permainan berbentuk persegi yang dilengkapi dengan kartu-kartu soal lengkap dengan kunci jawaban yang diberikan secara terpisah. Meskipun demikian terdapat beberapa hal yang membedakan monopoli tersebut. Monopoli karya Fajar memiliki ciri khas bertema nasionalisme, yaitu dengan mendesain papan permainan menggunakan tokoh pahlawan Indonesia serta terdapat soal-soal yang bertema Aku Cinta Indonesia. Adapun yang menjadi ciri khas dari monopoli Firdaus adalah adanya soal-soal beragam sesuai dengan tingkatan taksonomi Bloom. Monopoli karya Firdaus mengganti dadu menjadi pensil putar dan alat transaksi diganti dengan kartu denda, yaitu dengan mengurangi skor.

Keberadaan monopoli tersebut menginspirasi untuk dilakukan penelitian serupa dengan mengembangkan monopoli yang mengadaptasi hal-hal positif dalam monopoli 
sebelumnya dan menambahkan aspek-aspek lain sebagai ciri khas. Monopoli yang akan dikembangkan memilih materi peluang. Hal ini dikarenakan perhitungan dalam menjawab soal pada materi peluang dapat dilakukan dalam waktu yang relatif singkat. Selain itu, peluang merupakan salah satu materi yang sulit dikuasai oleh siswa. Hal ini terbukti dari daya serap hasil Ujian Nasional siswa SMP Tahun Ajaran 2014/2015 tingkat nasional 62,79 untuk materi peluang hanya 57,08\% dan 65,46\% (Puspendik, 2015). Meskipun telah mencapai lebih dari 50\%, namun tingkat ini masih tergolong rendah dibandingkan dengan materi pokok lainnya.

Monopoli yang akan dikembangkan pada penelitian ini tetap mempertahankan unsur nasionalisme. Unsur nasionalisme diwujudkan pada penguatan pendidikan karakter yang terdiri dari religius, nasionalis, mandiri, gotong royong, dan integritas serta ditambahkan untuk kasus positif dan negatif dalam kehidupan sehari-hari. Monopoli ini menggunakan nilai rupiah yang berada di Indonesia. Desain monopoli ini juga menggunakan tempat wisata yang ada di Indonesia. Monopoli ini mengadaptasi dan mengembangkan monopoli yang dimiliki Fajar. Oleh karena itu, Monomath milik Fajar disebut Monomath Series 1 dan Monomath ini disebut Monomath Series 2.

Monomath Series 2 ini tidak hanya menekankan nasionalisme, namun memiliki ciri khas Penguatan Pendidikan Karakter (PPK). PPK merupakan gerakan pendidikan di sekolah untuk memperkuat karakter melalui proses pembentukan, transformasi, dan pengembangan potensi peserta didik dengan cara harmonisasi olah hati (etik dan spiritual), olah rasa (estetik), olah pikir (literasi dan numerasi), dan olah raga (kinestetik) sesuai falsafah hidup Pancasila (Permendikbud, 2016). Menurut Tannir dan Al-Hroub (2013) "Character education is a development of the curriculum to educate students in order to knowledgeable and responsible so that has the skills of knowledge and ability required". Hal ini berarti pendidikan karakter dilakukan agar siswa memiliki ketrampilan, pengetahuan dan kemampuan sehingga siswa lebih bertanggungjawab. Gerakan PPK menempatkan pendidikan karakter sebagai inti pendidikan nasional, maka dari itu pendidikan karakter menjadi poros pelaksanaan pendidikan dasar dan menengah sehingga pendidikan karakter itu penting pada kurikulum 2013. Oleh karena itu, Monomath Series 2 juga akan bertujuan menanamkan pendidikan karakter.

Keunggulan lain dari Monomath Series 2 yang dikembangkan adalah adanya unsur level kognitif pada setiap soal. Soal akan terbagi menjadi 3 level yaitu Low Order 
Thinking Skills (LOTS), Medium Order Thinking Skills (MOTS) dan High Order Thinking Skills (HOTS). Menurut Widana (2017), setiap level memiliki tingkat kemampuan berpikir yang berbeda-beda. LOTS yang berisikan pengetahuan dan pemahaman yang mencangkup dimensi $(\mathrm{C} 1)$ proses berpikir mengetahui dan $(\mathrm{C} 2)$ memahami, MOTS yang berisikan aplikasi yang mencangkup dimensi (C3) proses berpikir menerapkan atau mengaplikasikan, dan HOTS berisikan penalaran yang mencangkup dimensi (C4) proses berpikir menganalisis, (C5) mengevaluasi dan (C6) mengkreasi.

Adanya beberapa aspek yang dimasukkan dalam menyusun Monomath Series 2 diharapkan tidak hanya dapat menjadikan proses menyelesaikan latihan soal menjadi lebih berbobot dan menarik dengan tingkat soal yang berjenjang. Namun, juga dapat memupuk nilai-nilai nasionalisme dan aspek-aspek dalam PPK. Selain itu, Monomath Series 2 juga diharapkan dapat dijadikan sarana untuk memperkenalkan kepada siswa bahwa di Indonesia kaya akan objek-objek wisata nan elok.

\section{METODE PENELITIAN}

Jenis penelitian ini yaitu penelitian pengembangan atau Research and Development (R\&D). Sugiyono (2015) menyatakan bahwa metode R\&D merupakan suatu proses meneliti, merancang, memproduksi dan menguji validitas produk yang telah dihasilkan secara ilmiah. Penelitian pengembangan ini bertujuan untuk mengembangkan suatu produk yang berupa media pembelajaran matematika berbasis permainan Monopoli untuk digunakan pada materi peluang di SMP.

Penelitian pengembangan ini menggunakan desain pengembangan pembelajaran model ADDIE. Model ini dikembangkan oleh Robert Maribe Branch (Pribadi, 2009) yang meliputi tahapan analisis (Analysis), tahap desain (Design), tahap pengembangan (Development), tahap implementasi (Implementation), serta tahap evaluasi (Evaluation).

Teknik pengumpulan data yang digunakan yaitu metode angket dan instrumen serta metode tes sebelum dan sesudah menggunakan media. Seluruh angket dikategorikan dengan kriteria penilaian yang dibagi menjadi 4 yaitu: 1) tidak setuju, 2) kurang setuju, 3) setuju, dan 4) sangat setuju. Data angket akan dihitung untuk memperoleh persentase hasil penilaian dengan menggunakan rumus : $\mathbf{P}(\mathbf{s})=\frac{S}{N} \times \mathbf{1 0 0 \%}$ 
Persentase hasil penilaian dikategorikan berdasarkan kriteria yang terdapat pada Tabel 1.

Tabel 1. Kriteria Penilaian Media

\begin{tabular}{ccc}
\hline No & Interval & Kriteria Penilaian \\
\hline 1 & $81 \% \leq$ skor $\leq 100 \%$ & Sangat Baik \\
\hline 2 & $61 \% \leq$ skor $\leq 80 \%$ & Baik \\
\hline 3 & $41 \% \leq$ skor $\leq 60 \%$ & Cukup Baik \\
\hline 4 & $21 \% \leq$ skor $\leq 40 \%$ & Tidak Baik \\
\hline
\end{tabular}

Hasil persentase akan menjadi kategori penilaian media Monomath Series 2. Media dikatakan valid dan praktis apabila persentase angket validasi lebih dari $61 \%$ atau berkategori baik dan persentase angket kepraktisan lebih dari $61 \%$ atau berkategori baik. Setelah media dikategorikan valid maka media siap untuk diujicobakan. Hasil yang berupa nilai awal (pretest) dan nilai akhir (posttest) akan diujikan menggunakan aplikasi SPSS. Terdapat uji parametric dengan pair t-test dan uji nonparametrik dengan Wilcoxon Signed Ranks. Data akan dilakukan uji normalitas terlebih dahulu untuk menentukan jenis uji yang digunakan. Media dikatakan efektif apabila hasil uji beda rerata antara pretest dan posttest menghasilkan nilai signifikan kurang dari 0,05 dengan rata-rata posttest lebih tinggi daripada rata-rata pretest.

\section{HASIL DAN PEMBAHASAN}

Penelitian ini merupakan penelitian pengembangan (Research and Development). Model penelitian pengembangan yang digunakan yaitu model pengembangan ADDIE. Penelitian ini sudah diterapkan pada siswa kelas IX-I SMP Negeri 1 Salatiga. Berikut uraian tahap-tahap pengembangan yang dilakukan.

1) Analyze (Analisis)

Tahap analisis pada penelitian ini terbagi menjadi 2 yaitu tahap analisis kinerja dan analisis kebutuhan. Analisis kinerja menunjukkan adanya permasalahan yang dibutuhkan pada proses latihan soal. Analisis kebutuhan (need analysis) memerlukan solusi yang berupa penyelenggaraan program pembelajaran yang dibutuhkan. Latihan soal dengan metode drill bisa menjadi jenuh. Oleh karena itu dibutuhkan media untuk dapat menyajikan latihan soal secara menarik. Permasalahannya adalah terbatasnya media yang ada. Hasil wawancara dengan guru menunjukkan bahwa pembelajaran di SMP Negeri 1 Salatiga sering menggunakan model pembelajaran Discovery Learning 
atau Problem Based Learning daripada menggunakan media pembelajaran terutama pada mata pelajaran Matematika. Terdapat beberapa materi dimana siswa lebih mudah memahami materi tersebut dengan menggunakan media daripada pembelajaran seperti pada umumnya. Akan tetapi, guru tidak sering menggunakan media pembelajaran dikarenakan tidak mempunyai waktu yang cukup dalam mengembangkan media untuk latihan soal sehingga media pembelajaran terbatas. Oleh karena itu, dibutuhkan suatu media dengan kriteria berikut: 1) media dapat digunakan siswa untuk berlatih soal secara rutin, 2) media dapat digunakan siswa tanpa merasa jenuh pada saat berlatih soal, dan 3) media dikemas secara ringkas dan praktis sehingga efektif untuk dibawa kemana-mana.

\section{2) Design (Desain)}

Setelah menemukan pokok permasalahan dan gambaran solusi pada tahap analisis maka dilakukan tahap desain untuk mewujudkan media yang sesuia dengan kriteria yang diinginkan. Salah satu alternatifnya yaitu mendesain sebuah media berupa monopoli. Media ini didesain secara menarik dan peraturan permainannya sama seperti monopoli pada umumnya sehingga siswa tidak terlalu lama untuk memahami aturan permainan pada media. Perangkat permainan monopoli seperti papan permainan, kartu komplek, kartu soal, kartu punishment, kartu reward, kartu pendidikan karakter, kartu beauty of mathematics serta buku petunjuk penggunaan juga didesain secara menarik agar siswa tertarik untuk memainkan media.

Berdasarkan aturan tersebut maka beberapa desain harus dilakukan. Pertama, mendesain papan permainan. Tema pada papan permainan yaitu Wonderful of Indonesia dengan menggunakan berbagai objek wisata yang berada di 6 pulau di Indonesia yaitu Pulau Sumatera, Jawa, Kalimantan, Bali sekitarnya, Sulawesi, dan Papua dengan setiap petak objek wisata terdapat harga jual dalam Rupiah. Desain papan Monomath Series 2 tidak berbentuk segi 4 pada umumnya, tetapi berbentuk segi 6 yang ditunjukkan pada Gambar 1. 


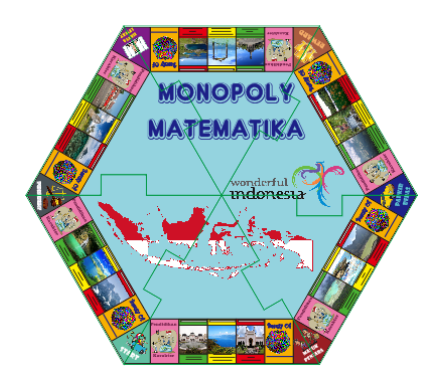

Gambar 1. Papan Permainan

Kedua, Monomath Series 2 didesain dengan soal-soal berbagai level kognitif yang berbeda yaitu Low Order Thinking Skill (LOTS) petaknya berwarna hijau, Medium Order Thinking Skill (MOTS) petaknya berwarna kuning dan High Order Thinking Skill (HOTS) petaknya berwarna merah yang ditunjukkan pada Gambar 2.

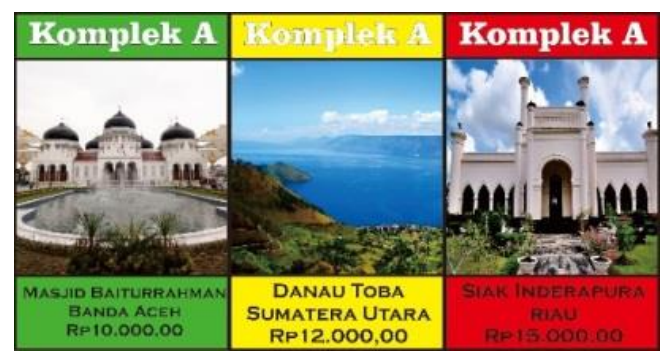

Gambar 2. Komplek A

Ketiga, mendesain kartu komplek. Kartu komplek atau biasa disebut dengan kartu sertifikat tanah didesain hampir sama seperti kartu komplek Monopoli pada umumnya. Terdapat harga sewa hanya tanah, rumah 1 sampai 4, hotel serta harga beli. Warna kartu komplek juga didesain sesuai pada warna petak yang ditunjukkan pada Gambar 3.

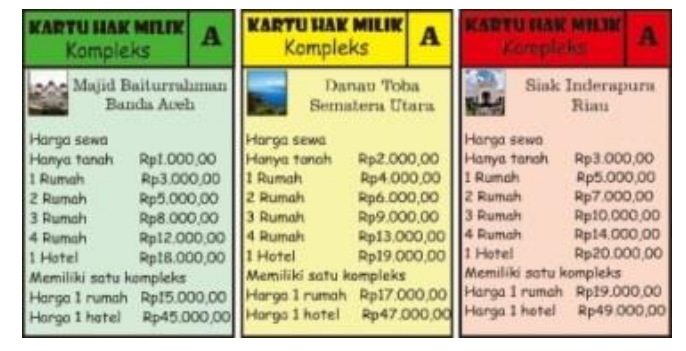

Gambar 3. Kartu Komplek 
Keempat, mendesain kartu soal. Pada materi peluang terdapat 4 indikator sehingga pembagian soal disetiap petaknya menjadi Sumatera (Komplek A) untuk indikator 1, Jawa (Komplek B) untuk indikator 2, Kalimantan (Komplek C) untuk indikator 3, Bali dan sekitarnya (Komplek D) untuk indikator 4, Sulawesi (Komplek E) untuk indikator 1 dan 2, Papua (Komplek F) untuk indikator 3 dan 4. Kartu soal didesain sesuai dengan warna pada petak komplek yang ditunjukkan pada Gambar 4.

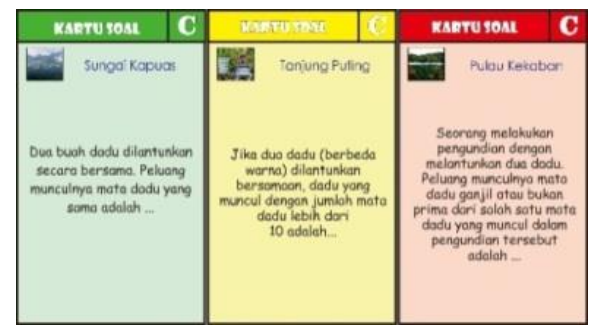

Gambar 4. Kartu Soal

Kelima, mendesain kartu punishment dan reward. Kartu punishment dan reward masing-masing berjumlah 12. Kartu punishment berisikan tentang hukuman yang harus dilakukan oleh pemain seperti membayar denda karena membuang sampah di objek wisata dan lain sebagainya. Sedangkan kartu reward berisikan tentang keuntungan yang diberikan oleh pemain seperti mendapatkan hadiah karena membantu turis asing dan lain sebagainya. Kartu punishment dan reward disajikan pada Gambar 5.

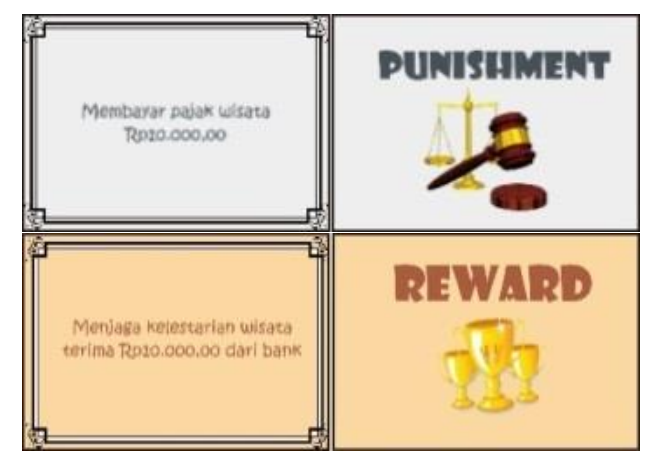

Gambar 5. Kartu Punishment dan Reward

Keenam, mendesain kartu Pendidikan Karakter. Penguatan Pendidikan Karakter (PPK) yang terdiri dari penguatan pendidikan Religius yang terdapat pada petak 1, Nasionalis pada petak 2, Mandiri pada petak 3, Gotong Royong pada petak 4, Integritas pada petak 5, dan kasus-kasus nyata dalam kehidupan sehari-hari baik dalam kasus positif atau kasus negatif pada petak 6. Ketujuh mendesain kartu beauty of mathematics. Kartu beauty of mathematics menjadi ciri khas pada Monomath Series 
2. Kartu Beauty of mathematics memuat soal-soal IQ yang berupa soal asah otak tentang beauty of mathematics menjadikan siswa dapat mengasah kemampuan berpikir. Kartu Pendidikan Karakter dan Beauty of Mathematics disajikan pada Gambar 6.

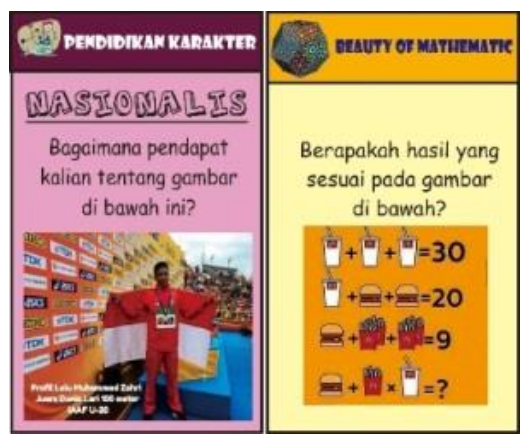

Gambar 6. Kartu Pendidikan Karakter dan Beauty of Mathematics

Kedelapan mendesain kelengkapan. Monomath Series 2 juga dilengkapi dengan dadu sebagai perhitungan langkah untuk pemain, rumah berwarna hijau dan hotel berwarna merah. Apabila pemain ingin mendirikan rumah atau hotel pada petak yang sudah dibeli, maka pemain harus mengerjakan soal terlebih dahulu. Terdapat pion sebagai pemain dalam permainan. Pion didesain dengan menggunakan orang-orangan yang memakai baju adat pada 6 pulau yang berada di Indonesia yaitu baju adat dari Jakarta, Kalimantan selatan, Sulawesi Tenggara, NTT, Papua dan Sumatera Barat sehingga siswa juga dapat mengenal baju adat khas Indonesia dari berbagai daerah dengan ciri khas masing-masing. Perlengkapan Monomath Series 2 disajikan pada Gambar 7.

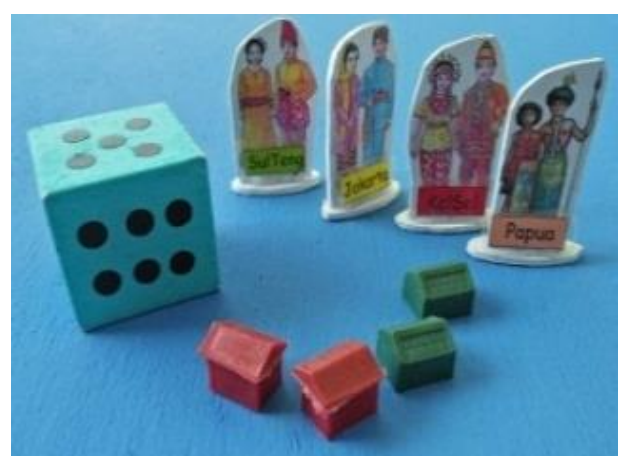

Gambar 7. Perlengkapan Monomath

Kesembilan, mendesain kemasan. Monomath Series 2 berbentuk segi enam yang berukuran kurang lebih 1 meter x 1 meter dikemas secara efektif dengan cara membuat papan menjadi bentuk puzzle segitiga sehingga media mudah dibawa kemana saja. 
Monomath Series 2 dikemas secara rapi dan efektif sehingga mudah dibawa kemana saja. Kartu soal terdapat pada bagian bawah petak dan dilengkapi dengan pita sehingga soal mudah diambil dan tidak berserakan. Selain itu uang, kartu punishment, reward dan kartu komplek disimpan dalam pocket yang dapat dilipat sehingga tidak memakan banyak tempat. Perlengkapan seperti kaki puzzle, pion, rumah dan hotel juga tidak berserakan karena ada pocket masing-masing. Pengemasan Monomath Series 2 disajikan pada Gambar 8. Permainan Monomath Series 2 dan kartu-kartu perangkat pendukungnya didesain dengan menggunakan software Corel Draw X7 Graphic dengan menggunakan warna yang dapat menarik perhatian terutama pada siswa SMP.

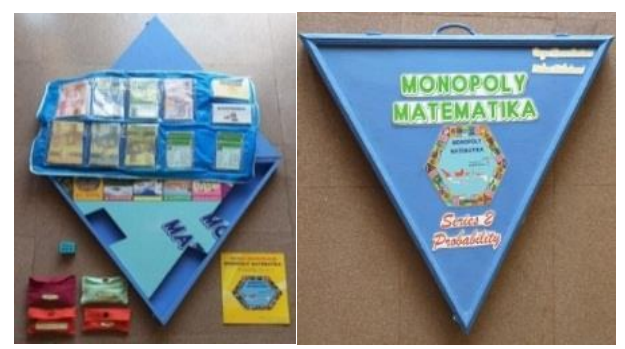

Gambar 8. Pengemasan Monomath

3) Development (Pengembangan)

Media Monomath Series 2 divalidasi oleh ahli materi dan ahli media. Validasi dilaksanakan untuk mendapatkan kritik dan saran dari para validator. Kritik dan saran validator akan menjadi acuan untuk memperbaiki media Monomath Series 2, sebagai berikut: 1) validator 1 memberikan saran, desain petak beauty of mathematics diubah menjadi gambar yang terkait dengan konsep matematika dan sebaiknya bahan yang digunakan lebih ringan, 2) validator 2 memberikan saran, merevisi kalimat soal yang terdapat pada kartu dan memberikan masukan untuk soal HOTS pada indikator frekuensi harapan, 3) validator 3 menyatakan bahwa media siap digunakan tanpa revisi. Setelah mendapatkan kritik dan saran kemudian media direvisi sebagaimana yang disajikan pada Tabel 2. 
Tabel 2. Revisi media berdasarkan kritik dan saran validator

\begin{tabular}{|c|c|c|c|}
\hline No & Sebelum di Revisi & Sesudah di Revisi & Keterangan \\
\hline 1) & & & $\begin{array}{l}\text { Desain dan perpaduan warna } \\
\text { papan permainan sesudah } \\
\text { direvisi warnanya tampak lebih } \\
\text { menarik dari pada gambar } \\
\text { sebelum direvisi }\end{array}$ \\
\hline 2) & Bearty Of & 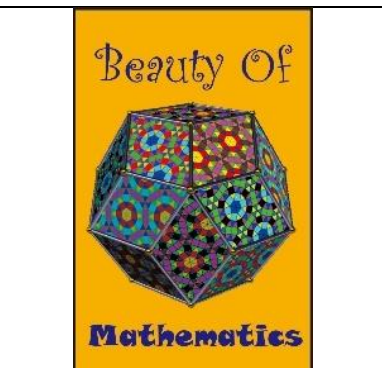 & $\begin{array}{c}\text { Desain dan warna pada petak } \\
\text { Beauty of Mathematics sesudah } \\
\text { di revisi warnanya tampak lebih } \\
\text { cerah dari gambar sebelum } \\
\text { direvisi }\end{array}$ \\
\hline 3) & $\begin{array}{l}\text { Setiap hari suatu } \\
\text { perusahaan dapat } \\
\text { memproduksi } 1.500 \text { gelas. } \\
\text { Jika peluang sebuah gelas } \\
\text { yang dihasilkan tidak } \\
\text { cacat adalah } \frac{4}{5} \text {, maka } \\
\text { banyaknya gelas yang } \\
\text { cacat ada ... }\end{array}$ & $\begin{array}{l}\text { Setiap hari suatu } \\
\text { perusahaan dapat } \\
\text { memproduksi } 1.500 \text { gelas. } \\
\text { Jika peluang sebuah gelas } \\
\text { yang dihasilkan cacat } \\
\text { adalah } \frac{1}{5} \text {, peluang gelas } \\
\text { pecah setengah dari yang } \\
\text { cacat, maka banyaknya } \\
\text { gelas yang tidak cacat } \\
\text { adalah ... }\end{array}$ & $\begin{array}{l}\text { Tingkat kesulitan soal yang } \\
\text { sudah direvisi lebih tinggi dari } \\
\text { soal yang sebelum direvisi }\end{array}$ \\
\hline
\end{tabular}

\section{4) Implementation (Implementasi)}

Monomath Series 2 diukur kelayakannya dengan melakukan validasi. Validasi yang dilakukan terdiri dari validasi ahli media dan validasi ahli materi. Validator ahli media terdiri atas 1 dosen Prodi Pendidikan Matematika FKIP UKSW, 1 dosen Prodi Matematika FKIP UKSW, dan 1 guru matematika kelas IX SMP Negeri 1 Salatiga. Hasil validasi disajikan pada Tabel 3 berikut.

Tabel 3. Validasi Ahli Media

\begin{tabular}{ccc}
\hline Aspek Penilaian & Persentase & Kategori \\
\hline Aspek Tampilan & $81,7 \%$ & Sangat Baik \\
Aspek Aturan Permainan & $77,1 \%$ & Baik \\
Aspek Pembuatan & $75 \%$ & Baik \\
Aspek Penggunaan dan Pemeliharaan & $76,7 \%$ & Baik \\
Aspek Kebermanfaatan & $83,3 \%$ & Sangat Baik \\
Aspek Pengemasan & $75 \%$ & Baik \\
\hline Rata-rata & $78,1 \%$ & Baik \\
\hline
\end{tabular}


Hasil persentase tiap aspek pada kategori di atas berkategori baik karena persentase lebih dari 60\%. Dengan demikian media Monomath Series 2 valid dengan persentase rata-rata sebesar 78,1\% (baik). Adapun validator ahli materi, yaitu 1 dosen Prodi Pendidikan Matematika FKIP UKSW, 1 dosen Prodi Matematika FKIP UKSW, dan 1 guru matematika kelas IX SMP Negeri 1 Salatiga. Hasil validasi disajikan pada Tabel 4 berikut.

Tabel 4. Validasi Ahli Materi

\begin{tabular}{ccc}
\hline Aspek Penilaian & Persentase & Kategori \\
\hline Aspek Materi & $77,1 \%$ & Baik \\
Aspek Kontruksi & $83,3 \%$ & Sangat Baik \\
Aspek Keberagaman Soal & $81,3 \%$ & Sangat Baik \\
Aspek Beauty of Mathematics & $83,3 \%$ & Sangat Baik \\
Aspek Pendidikan Karakter dan Cinta Tanah Air & $79,2 \%$ & Baik \\
\hline Rata-rata & $80,8 \%$ & Baik \\
\hline
\end{tabular}

Hasil persentase tiap aspek pada kategori di atas berkategori baik karena persentase lebih dari 60\%. Dengan demikian, materi pada Monomath Series 2 valid dengan persentase $80,8 \%$ (baik).

Berdasarkan hasil di atas, validasi ahli materi dan ahli media dengan persentase rata-rata sebesar $80,8 \%$ dan $78,1 \%$, maka dapat disimpulkan bahwa media Monomath Series 2 dinyatakan valid untuk pembelajaran materi Peluang.

Monomath Series 2 telah diujicobakan pada awal bulan September di kelas IXI SMP Negeri 1 Salatiga. Pada saat uji lapangan siswa sangat antusias melakukan permainan dan belajar menggunakan media Monomath Series 2 sehingga siswa gaduh pada saat proses pembelajaran. Meskipun gaduh siswa tetap antusias dan semangat dalam mengerjakan soal. Untuk mengatasi kegaduhan tersebut, peneliti memegang dadu sehingga kelompok tidak bermain menggelindingkan dadu tanpa perintah dan pembelajaran kembali berjalan secara efektif.

Setelah dilakukan uji lapangan, uji kepraktisan juga dilakukan dengan pengisian angket oleh validator. Validator kepraktisan ini yaitu 2 guru matematika SMP Negeri 1 Salatiga. Hasil validasi disajikan pada Tabel 5 berikut.

Tabel 5. Validasi Uji Kepraktisan

\begin{tabular}{ccc}
\hline Aspek Penilaian & Persentase & Kategori \\
\hline Aspek Persiapan & $83,3 \%$ & Sangat Baik \\
Aspek Penggunaan & $76,8 \%$ & Baik \\
Aspek Perawatan dan Penyimpanan & $87,5 \%$ & Sangat Baik \\
\hline Rata-rata & $82,5 \%$ & Sangat Baik \\
\hline
\end{tabular}


Berdasarkan hasil validasi uji kepraktisan dari beberapa aspek diperoleh persentase rata-rata sebesar $82,5 \%$ (sangat baik), maka dapat disimpulkan bahwa media Monomath Series 2 dikatakan praktis dari setiap aspek dengan kategori sangat baik.

\section{5) Evaluation (Evaluasi)}

Hasil belajar diukur pada saat sebelum dan sesudah menggunakan Monomath Series 2. Tes awal (pretest) yang terdiri dari 4 indikator dan setiap indikator terdiri dari 2 soal sehingga soal berjumlah 8 , kemudian siswa diminta untuk belajar menggunakan Monomath Series 2. Setelah menggunakan media siswa diminta untuk mengerjakan tes (posttest) yang terdiri dari dari 4 indikator dan setiap indikator terdiri dari 2 soal sehingga soal berjumlah 8 . Hasil pretest dan posttest dibandingkan dan dapat dilihat pada Tabel 6 .

Tabel 6. Hasil Pretest dan Posttest Descriptive Statistics

\begin{tabular}{|c|c|c|c|c|c|}
\hline & N & Minimum & Maximum & Mean & Std. Deviation \\
\hline Pretest & 24 & 13 & 100 & 54.83 & 23.170 \\
Posttest & 24 & 75 & 100 & 95.46 & 6.574 \\
Valid N (listwise) & 24 & & & & \\
\hline
\end{tabular}

Hasil pretest dan posttest menyatakan bahwa terjadi peningkatan nilai. Pada pretest nilai minimal adalah 13 dan nilai maksimal adalah 100 sehingga nilai rata-rata adalah 54,83. Sedangkan pada posttest nilai minimal adalah 75 dan nilai maksimal adalah 100 sehingga nilai rata-rata adalah 95,46. Guna menguji keefektifan media dalam populasi yaitu siswa SMP, maka dilakukan uji inferensial. Langkah awal adalah melakukan uji normalitas. Hasil uji normalitas dapat dilihat pada Tabel 7.

Tabel 7. Hasil Uji Normalitas

\section{Tests of Normality}

\begin{tabular}{|l|r|r|r|r|r|r|}
\hline \multirow{2}{*}{} & \multicolumn{3}{|c|}{ Kolmogorov-Smirnov } & \multicolumn{3}{c|}{ Shapiro-Wilk } \\
\cline { 2 - 7 } & \multicolumn{1}{|c|}{ Statistic } & Df & \multicolumn{1}{c|}{ Sig. } & Statistic & Df & Sig. \\
\hline Pretest & .183 & 24 & .037 & .922 & 24 & .065 \\
Posttest & .339 & 24 & .000 & .716 & 24 & .000 \\
\hline
\end{tabular}

a. Lilliefors Significance Correction

Berdasarkan hasil uji normalitas pada Tabel 7 dapat dilihat nilai signifikansi pretest sebesar $0,065(>0,05)$. Hal tersebut berarti nilai pretest berasal dari populasi yang berdistribusi normal. Akan tetapi, posttest tertulis .000 yang artinya mendekati 0 $(<0,05)$. Hal tersebut berarti posttest tidak berasal dari populasi yang berdistribusi 
normal. Oleh karena itu, uji yang akan digunakan adalah uji non parametrik untuk data berelasi yaitu Wilcoxon Signed Ranks. Hasil uji ini dapat dilihat pada Tabel 8.

Tabel 8. Hasil Uji Wilcoxon Signed Ranks

Ranks

\begin{tabular}{|c|r|r|r|}
\hline & N & Mean Rank & Sum of Ranks \\
\hline Nilai_Akhir - Nilai_Awal Negative Ranks & $0^{\mathrm{a}}$ & .00 & .00 \\
Positive Ranks & $23^{\mathrm{b}}$ & 12.00 & 276.00 \\
Ties & $1^{\mathrm{c}}$ & & \\
Total & 24 & & \\
\hline
\end{tabular}

a. Nilai_Akhir $<$ Nilai_Awal
b. Nilai_Akhir $>$ Nilai_Awal
c. Nilai_Akhir $=$ Nilai_Awal

Test Statistics ${ }^{\mathrm{b}}$

\begin{tabular}{|l|c|}
\hline & Nilai_Akhir - Nilai_Awal \\
\hline Z & $-4.211^{\mathrm{a}}$ \\
Asymp. Sig. (2-tailed) & .000 \\
\hline
\end{tabular}

a. Based on negative ranks.

b. Wilcoxon Signed Ranks Test

Berdasarkan Tabel 8 pada negative ranks, nilai akhir - nilai awal $<0$ sebanyak 0 sampel. Hal itu berarti tidak ada siswa yang nilai awalnya lebih baik dari nilai akhir. Pada positive ranks, nilai akhir - nilai awal $>0$ sebanyak 23 sampel. Hal itu berarti terdapat 23 sampel yang nilai akhirnya meningkat dari nilai awalnya. Pada ties, nilai akhir - nilai awal $=0$ sebanyak 1 sampel. Hal itu berarti terdapat 1 sampel yang nilai awalnya sama dengan nilai akhir. Signifikansi tertulis .000 artinya mendekati 0 yang kurang dari 0,05. Oleh karena itu, dapat disimpulkan bahwa nilai posttest secara signifikan lebih baik dari pada nilai pretest. Berdasarkan hasil uji tersebut, dapat disimpulkan bahwa Monomath Series 2 efektif digunakan sebagai media latihan soal untuk materi peluang pada siswa SMP Negeri 1 Salatiga. Data kualiatatif pendapat siswa mengenai media pembelajaran Monomath Series 2 disajikan pada Tabel 9.

Tabel 9. Hasil Pendapat Siswa

\begin{tabular}{ccc}
\hline Pendapat Media & Persentase & Kategori \\
\hline Mudah dipahami & $90 \%$ & Sangat Baik \\
Penggunaan Mudah & $85 \%$ & Sangat Baik \\
Asyik dan Menantang & $96 \%$ & Sangat Baik \\
Bermain dan Belajar & $94 \%$ & Sangat Baik \\
Memahami Materi & $86 \%$ & Sangat Baik \\
\hline Rata-rata & $90 \%$ & Sangat Baik \\
\hline
\end{tabular}

Berdasarkan hasil pendapat siswa kelas IX-I SMP Negeri 1 Salatiga yang 
bejumlah 24 siswa, dari tiap aspek pendapat mereka menyatakan bahwa media Monomath Series 2 berkategori sangat baik dengan persentase pendapat siswa mengenai media rata-rata adalah 90\%. Oleh karena itu, dapat disimpulkan bahwa respon siswa terhadap Monomath Series 2 sangat baik digunakan pada saat proses pembelajaran matematika.

\section{SIMPULAN DAN SARAN}

Hasil penelitian menunjukkan bahwa uji validasi media dan validasi materi berturut-turut menghasilkan persentase rata-rata sebesar 78,1\% (baik) dan 80,8\% (baik). Dengan demikian media Monomath Series 2 valid untuk digunakan. Adapun uji kepraktisan dengan persentase rata-rata $82,5 \%$ (sangat baik). Hal tersebut berarti media praktis untuk digunakan pada saat pembelajaran. Hasil uji pretest dan posttest dengan menggunakan uji Wilcoxon Signed Ranks menghasilkan signifikan mendekati 0 yang kurang dari 0,05 dengan nilai rata-rata posttest $(95,46)$ lebih tinggi daripada nilai rata-rata pretest $(54,83)$. Hal ini berarti nilai posttest secara signifikan lebih baik dibandingkan nilai pretest. Selain itu, 90\% siswa memberikan respon positif terhadap penggunaan Monomath Series 2 dalam pembelajaran dengan kategori sangat baik. Hal tersebut berarti media Monomath Series 2 efektif digunakan oleh siswa. Berdasarkan hasil persentase penelitian pengembangan yang telah dilaksanakan dapat disimpulkan bahwa media Monomath Series 2 dinyatakan valid, praktis, dan efektif untuk digunakan sebagai media latihan soal pada materi peluang di SMP.

Penelitian ini telah mengembangkan media Monomath Series 2 yang valid, praktis dan efektif. Oleh karena itu, disarankan bagi guru agar menggunakan Monomath Series 2 sebagai media latihan soal pada materi peluang untuk siswa SMP. Guru juga dapat mengembangkan media monopoli pada materi atau mata pelajaran lainnya. Selain itu, diharapkan peneliti yang lain dapat mengembangkan media berupa monopoli versi yang lain dengan memasukkan unsur-unsur lainnya seperti mengangkat kearifan lokal suatu daerah dan lain sebagainya. 


\section{DAFTAR PUSTAKA}

Acharya, B. R. (2017). Factors Affecting Difficulties in Learning Mathematics by Mathematics Learners. International Journal of Elementary Education, 6(2), 8-15.

Arsyad, A. (2011). Media Pembelajaran. Jakarta: Rajawali Press.

Fajar, M. \& Prihatnani, E. (2018). Pengembangan Permainan Monomath Pada Materi Persamaan Garis Lurus Bagi Siswa Kelas VIII SMP Negeri 10 Salatiga. Jurnal STKIP Bina Bangsa Meulaboh, 5(1), 14-26.

Fitri, R., Helma, \& Syarifuddin, H. (2014). Penerapan Strategi The Firing Line Pada Pembelajaran Matematika Siswa Kelas XI IPS SMA Negeri 1 Batipuh. Jurnal Pendidikan Matematika Universitas Negeri Padang, 3(1), 18-22.

Firdaus, Z. (2015). Pengembangan Media Pembelajaran Monopoli IPA Materi Sistem Pencernaan Makanan Untuk Siswa Kelas VIII Di SMP Negeri 4 Malang. Fakultas MIPA UM, 1(1), 1-12.

Indriana, D. (2011). Ragam alat bantu Media Pengajaran. Yogyakarta: Diva Press.

Kustandi, C., \& Sutjipto, B. (2011). Media Pembelajaran Manual dan Digital. Bogor: Ghalia Indonesia.

Permendikbud. (2016). Konsep dan Pedoman Penguatan Pendidikan Karakter Tingkat Sekolah Dasar dan Sekolah Menengah Pertama.

Pribadi, B. A. (2009). Model Desain Sistem Pembelajaran. Jakarta: PT Dian Rakyat.

Ramadhani, N. (2016). Pengembangan Media Educational Game "Monopoly Fisika (MOSIK)" Pada Mata Pelajaran IPA di SMP. Jurnal Pembelajaran Fisika, 5(3), 235-245.

Ramadhani, R. (2017). Peningkatan Kemampuan Pemahaman Konsep dan Kemampuan Pemecahan Masalah Matematika Siswa SMA Melalui Guided Discovery Learning Berbantu Autograph. Jurnal Penelitian dan Pembelajaran Matematika Untirta, 10(2), 72-81.

Rahaju, R. \& Hartono, S. R. (2015). Pembelajaran Matematika Berbasis Pemainan Monopoli Indonesia. Jurnal Ilmiah Pendidikan Matematika, 2(2), 130-139.

Rohana, R., Hartono, Y., \& Purwoko. (2009). Penggunaan Peta Konsep dalam Pembelajaran Statistika Dasar di Program Studi Pendidikan Matematika FKIP Universitas PGRI Palembang. Jurnal Pendidikan Matematika Universitas Sriwijaya, 3(2), 92-102.

Sagala, S. (2012). Konsep dan Makna Pembelajaran. Bandung: Alfabeta.

Sanaky, H. (2009). Media Pembelajaran. Yogyakarta: Safiana Insania Press. 
Sudjana, N. (1995). Dasar-Dasar Proses Belajar Mengajar. Bandung: Sinar Baru Algensindo.

Sudjana, N. \& Rivai, A. (2013). Media Pengajaran (cetakan ke-11). Bandung: Sinar Baru Algesindo.

Sugiyono. (2015). Metode Penelitian Kombinasi. Bandung: Alfabeta.

Supriyono. (2012). Mengenal Tugas Akhir Program. Salatiga: Widya Sari Press.

Tang, S., Hanneghan, M., \& El-Rhalibi, A. (2009). Introduction to Games-Based Learning. In T. M. Connolly, M. H. Stansfield \& L. Boyle (Eds.), Games-Based Learning Advancements for Multi-Sensory Human Computer Interfaces: Techniques and Effective Practices (pp. 1-17). Hershey: Idea-Group Publishing.

Tannir, A. \& Al-Hroub, A. (2013). Effects of Character Education on The Self-Esteem of Intellectually Able and Less Able Elementary Students in Kuwait. International Journal of Special Education, 28(1), 47-59

Trinovitasari, A. (2015). Penggunaan Permainan Monopoli Sebagai Media Pembelajaran Dalam Meningkatkan Motivasi Belajar Ilmu Pengetahuan Sosial Siswa Sekolah Menengah Pertama. Skripsi. Fakultas Ilmu Tarbiyah dan Keguruan UIN Syarif Hidayatullah

Widana, W. (2017). Modul Penyusunan Soal Higher Order Thinking Skill (HOTS). Jakarta: Dirjen Pembinaan SMA Kementerian Pendidikan dan Kebudayaan. 